\title{
GENETIC AND AGGRESSIVENESS VARIATION AMONG Sclerotinia sclerotiorum DRY BEAN ISOLATES FROM BRAZIL FIELDS
}

\section{VARIAÇÃO GENÉTICA E AGRESSIVIDADE ENTRE ISOLADOS DE Sclerotinia sclerotiorum PROVINDOS DE CAMPOS DE FEIJÃO DO BRASIL}

\author{
Willian Luis Antonio ZANCAN ${ }^{1}$; James R. STEADMAN ${ }^{2}$; Rebecca HIGGINS ${ }^{2}$; \\ Rachana JHALA ${ }^{2}$; José da Cruz MACHADO ${ }^{1}$ \\ 1. Universidade Federal de Lavras - UFLA, Lavras, MG, Brazil; 2. University of Nebraska-Lincoln - UNL, Lincoln, NE, USA. \\ zancanwillian@gmail.com
}

\begin{abstract}
Sclerotinia sclerotiorum, infection of bean fields, has increased in Brazil. Fungicides application is the control strategy used due to lack of cultivars with complete disease resistance. To guide the use of isolates in resistance screening $25 \mathrm{~S}$. sclerotiorum isolates from Brazilian dry bean fields were characterized using microsatellite markers, mycelial compatibility groups (MCGs) and aggressiveness. Microsatellite primer pairs were used to identify polymorphisms among the $S$. sclerotiorum isolates and MCGs were determined from interaction of all isolates grown sideby-side. Aggressiveness was derived from a straw test where fungal mycelium was placed over a cut bean stem and rated for disease progress. Data from microsatellite profiles grouped the 25 isolates into four clusters and seven MCGs were identified. No association among host cultivar and cluster or MCG of isolates was observed. For MCGs, 57\% contained isolates sampled frequently over multiple locations and $43 \%$ contained isolates unique to locations. There were significant differences among isolates in aggressiveness within and between MCGs. The most aggressive isolates in resistance screening will be helpful in the identification of higher levels of resistance in bean germplasm/lines.
\end{abstract}

KEYWORDS: Aggressiveness. Microsatellites. Resistance. White mold.

\section{INTRODUCTION}

Sclerotinia sclerotiorum (Lib.) de Bary, causal agent of white mold on dry bean (Phaseolus vulgaris L.), is among the most devastating and promiscuous necrotrophic fungal plant pathogens, having a diverse host range, including weed species and causes yield losses in many important agronomic crops (BOLTON et al., 2006).

To establish management strategies it is important to understand the variation nature of that pathogen in population and aspects of epidemiology. Sclerotinia sclerotiorum has a haploid somatic phase in which clonality is the result of both asexual reproduction by means of sclerotia and sexual reproduction by selffertilization (KOHN 1995) with the expectation that intraclonal variation is due to mutation (CARBONE et al. 1999; CARBONE; KOHN 2001; HAMBLETON et al., 2002).

Microsatellite alleles are often closely associated with mycelial compatibility, an independent marker used to genotype isolates and thought to be under multigenic regulation (SCHAFER; KOHN, 2006; CLARKSON et al., 2013). Microsatellite markers have been very informative in studying genetic diversity and population biology of $S$. sclerotiorum due to the high mutation rates that are multiallelic in nature, which makes them useful in phylogenetic inference (SIRJUSINGH; KOHN, 2001).

In previous studies on $S$. sclerotiorum variation, mycelial compatibility groupings (MCGs) were used to measure population diversity among pathogen isolates. Mycelial compatibility/incompatibility grouping is a self and nonself recognition system controlled by multiple loci (BOLTON et al., 2006). High genetic variability of isolates from bean, tomato, pepper, lentil, sunflower, carrot, radish, canola and cabbage of wide geographical origin in Brazil was reported using RAPD markers and MCGs (LITHOLDO JÚNIOR et al., 2011).

In addition to genetics, $S$. sclerotiorum isolates can be characterized by measuring aggressiveness on a resistant host. Pathogenicity may be evaluated in many ways such as infection efficiency, latent period, sporulation rate, infectious period or lesion size (PARIUAD et al., 2009). By measuring lesion progress on stems over time, OttoHanson et al. (2011) found that S. sclerotiorum isolates collected from dry bean fields in Minnesota were more aggressive than isolates from Nebraska, Michigan and Washington, whereas California isolates were less aggressive than those collected from all other bean production locations.

Disease control through crop management practices has contributed to decrease the inoculum 
of fungi, especially soilborne, in different regions of the world, but the effectiveness of management strategies is directly related to the aggressiveness of the remaining inoculum (HAWTHORNE; JARVIS, 1973).

The objective in this study was to expand the knowledge on characterization of $S$. sclerotiorum isolates collected in dry bean fields in Brazil. Genetic variation and aggressiveness were measured.

\section{MATERIAL AND METHODS}

\section{Sclerotinia sclerotiorum isolates}

Twenty-five Sclerotinia sclerotiorum isolates were obtained from different dry bean cultivars grown in different states in Brazil: Minas Gerais (17), Goiás (5), Bahia (1), Mato Grosso (1) and Paraná (1) between 2009 and 2012 (Table 1). For each isolate in each field, sclerotia were collected from infected plants in each state and collection year.

Table 1. Collection information for each bean isolate of Sclerotinia sclerotiorum in Brazil.

\begin{tabular}{ccccc}
\hline Field & Isolate Number & Year & Location & Host cultivar \\
\hline 1 & 10 & 2011 & São Desidério, BA & BRS Ametista \\
2 & 25 & 2011 & Montividiu, GO & Pérola \\
3 & 17 & 2011 & Silvânia, GO & Pérola \\
4 & $51 \mathrm{C}$ & 2009 & Rio Verde, GO & Pérola \\
5 & $54 \mathrm{C}$ & 2010 & Rio Verde, GO & Pérola \\
6 & 26 & 2010 & Campo Verde, MT & Pérola \\
7 & $63 \mathrm{~F}$ & 2011 & Lavras, MG & BRSMG Talismã \\
8 & 40 & 2009 & Ijací, MG & BRSMG Talismã \\
9 & $70 \mathrm{~B}$ & 2011 & Patos de Minas, MG & BRSMG Majestoso \\
10 & $57 \mathrm{~A}$ & 2012 & Ventania, PR & BRS Pontal \\
11 & $60 \mathrm{~A}$ & 2011 & Irai de Minas, MG & BRS Majestoso \\
12 & $61 \mathrm{~B}$ & 2010 & Unaí, MG & IAPAR 81 \\
13 & $56 \mathrm{~F}$ & 2010 & Unaí, MG & Juriti \\
14 & 53B & 2010 & Paracatu, MG & Peróla \\
15 & $53 \mathrm{C}$ & 2010 & Paracatu, MG & Peróla \\
16 & $67 \mathrm{~A}$ & 2010 & Coimbra, MG & Ouro Vermelho \\
17 & $69 \mathrm{C}$ & 2011 & Goiânia, GO & BRS Monarca \\
18 & 66E & 2010 & Oratórios, MG & Ouro Vermelho \\
19 & 65B & 2010 & Canaã, MG & Ouro Vermelho \\
20 & 64D & 2010 & Viçosa, MG & BRSMG Majestoso \\
21 & 71A & 2010 & Porto Firme, MG & Ouro Vermelho \\
22 & 71B & 2010 & Porto Firme, MG & Ouro Vermelho \\
23 & 52C & 2010 & Porto Firme, MG & Ouro Vermelho \\
24 & 43 & 2010 & Lambari, MG & S 35 MA 2 \\
25 & $58 \mathrm{C}$ & 2010 & Lambari, MG & Marcela81 \\
\hline & & & &
\end{tabular}

Mycelial cultures of $S$. sclerotiorum used in characterization studies were reactivated from stored sclerotia by surface sterilization and growing on media in Petri dishes. Once collected, the isolates were stored in $1.5 \mathrm{ml}$ microcentrifuge tubes at $5^{\circ} \mathrm{C}$. Sclerotia were triple rinsed with (i) $50 \%$ Clorox bleach $/ 50 \%$ double-distilled (dd) $\mathrm{H}_{2} \mathrm{O}$ solution for 3 min, (ii) $d_{d d H_{2}} \mathrm{O}$ rinse for $3 \mathrm{~min}$, and (iii) a final $\mathrm{ddH}_{2} \mathrm{O}$ rinse for $3 \mathrm{~min}$, then plated on water agar ( $16 \mathrm{~g}$ of Bacto agar per liter of $\mathrm{ddH}_{2} \mathrm{O}$ ), with four to five sclerotia of each isolate separated on each plate and incubated at $20-22{ }^{\circ} \mathrm{C}$ for 5 to 6 days. An 8-mm plug from a 5- or 6-day-old culture was transferred from the margin of the mycelial colony onto a Petri dish containing PDA (Difco potato dextrose agar at $39 \mathrm{~g} /$ liter of $\mathrm{ddH}_{2} \mathrm{O}$ ) and incubated at $20-22{ }^{\circ} \mathrm{C}$ for 2-3 days.

\section{Molecular characterization}

Isolates from all collections were characterized using microsatellite markers and then analyzed for DNA genotype by an ABI 3700 
Genetic Analyzer (Applied Biosystems). Isolate cultures derived from stock sclerotia were subcultured onto PDA and incubated at $20-22{ }^{\circ} \mathrm{C}$. After 3 days, four agar plugs from the colony margin were transferred to a flask containing $150 \mathrm{ml}$ PDB (potato dextrose broth at $24 \mathrm{~g} /$ liter of $\mathrm{ddH}_{2} \mathrm{O}$ ) and incubated for 3-4 days at 20-22 ${ }^{\circ} \mathrm{C}$. The resultant mycelial mat was removed and rinsed with $\mathrm{ddH}_{2} \mathrm{O}$ using a Buchner funnel before being blotted dry and lyophilized. Total genomic DNA was extracted from approximately $0.01 \mathrm{~g}$ lyophilized mycelium using phenol/chloroform extraction protocol (Sambrook and Russel, 2001).

\section{Microsatellite analysis}

Eight fluorescently-labelled microsatellite primer pairs were chosen from the 25 microsatellite primer pairs developed by Sirjusingh and Kohn (2001), to identify polymorphisms among the $S$. sclerotiorum isolates. These primer pairs were used in multiplex PCR amplifications for sets of two (72, 20-3; 6-2, 110-4; 36-4, 114-4; and 106-4, 92-4) microsatellite loci (Sirjusingh and Kohn, 2001). Polymerase chain reaction (PCR) amplification mixtures of $25 \mu \mathrm{l}$ contained $5.0 \mu \mathrm{M}$ of each primer, $5 \mathrm{mM}$ dNTPs, $50 \mathrm{mM} \mathrm{MgCl}_{2}, 10 \mathrm{x}$ buffer (TaKaRa Ex Taq $\left.^{\mathrm{TM}}\right), 0.65 \mathrm{U}$ of TaKaRa Ex Taq ${ }^{\mathrm{TM}}$ DNA polymerase, and $2.0 \mu \mathrm{l}$ of a $20 \mathrm{ng} / \mu \mathrm{l}$ genomic DNA solution. Amplifications were performed in a Labnet MultiGene Thermal Cycler TC9600-G programmed for an initial denaturation at $95^{\circ} \mathrm{C}$ for $8 \mathrm{~min}$, followed by 35 cycles of denaturation at $95^{\circ} \mathrm{C}$ for 30 sec; primer annealing at $56^{\circ} \mathrm{C}$ for $45 \mathrm{sec}$; and extension at $65^{\circ} \mathrm{C}$ for $90 \mathrm{sec}$, with a 30 -min extension at $65^{\circ} \mathrm{C}$ on the final cycle. PCR products were visualized by gel electrophoresis to confirm the amplification of the microsatellite loci in that isolate. PCR amplicons giving visible bands on the gel were diluted 1:50 in $\mathrm{ddH}_{2} \mathrm{O}$ to optimize fluorescent signals and performed fragment analysis by an ABI 3700 Genetic analyzer. Data collected after DNA genotyping were analyzed using Peak Scanner software (Applied Biosystems).

\section{Mycelial Compatibility Grouping (MCG)}

S. sclerotiorum isolates were also used for mycelial compatibility trial. For that, an $8 \mathrm{~mm}$ water agar plug was taken from approximately $1 \mathrm{~mm}$ behind the colony edge and placed mycelia side down on a plate of Diana Sermons (DS) medium (CUBETA et al., 2001). The medium consisted of malt extract broth at $40 \mathrm{~g} /$ liter (Sigma-Aldrich, St. Louis), $\mathrm{NaCl}$ at $20 \mathrm{~g} / \mathrm{liter}$, Bacto peptone at $5 \mathrm{~g} / \mathrm{liter}$ (BD Diagnostic Systems, Sparks, MD), Bacto agar at $15 \mathrm{~g} / \mathrm{liter}$ (BD Diagnostic Systems),
McCormick's red food dye $(80 \mu 1 /$ liter $)$ and McCormick's yellow food dye ( $80 \mu 1 /$ liter). Isolates were grown on DS media plates for $48 \mathrm{~h}$ on the bench top at $20-22{ }^{\circ} \mathrm{C}$ before use in an MCG test. To determine the MCGs, each possible pair of isolates was grown in a side-by-side pairing by placing an $8 \mathrm{~mm}$ plug of an isolate from DS culture on a plate of DS medium, $2.5 \mathrm{~cm}$ apart. Each isolate pairing was duplicated and each pairing was incubated on the bench top at $20-22{ }^{\circ} \mathrm{C}$ for 7 days. The reaction between each isolate pair was evaluated at 7 and 14 days after transfer by three different observers. Pairings were scored as compatible when the two strains merged to form one colony, with no distinct interaction zone. Pairings were scored as incompatible when the cultures formed a barrage line of dead cells and reduced growth between the two isolates (KOHN et al., 1990). The results were recorded in a matrix, as either an incompatible or a compatible reaction for each isolate pair. The experimental design was a randomized complete block with 2 replications.

\section{Aggressiveness}

The straw test, as described by Otto-Hanson et al. (2011) was conducted in the greenhouse at $20^{\circ} \mathrm{C}$ nighttime and $26^{\circ} \mathrm{C}$ daytime temperatures. For inoculation, clear drinking straws were cut to $1.5 \mathrm{~cm}$ in length and heat sealed at one end. The open end of the straw was pressed into the reverse side of a 23 day old PDA culture at the advancing edge of the mycelia of each $S$. sclerotiorum isolate. The stem of each bean plant was cut $2 \mathrm{~cm}$ above the fourth node (the internode between the fourth and fifth node). The straw containing agar and fungal mycelium was placed over the cut stem, and the plants were incubated for 8 days when they were rated using the "Modified Petzoldt and Dickson Scale" (TERAN et al., 2006). This rating scale is used for screening bean lines for white mold reaction: a rating of 1 to 3 is considered resistant (1. plants without symptoms; 2 . invasion of the fungus beyond inoculation site $<$ inch; 3. invasion of the fungus near the first internode $>$ linch), 4 to 6 is considered intermediate (4. fungus expanded to the fist internode; 5 . invasion of the fungus beyond the first internod $<1$ inch; 6 . invasion of the fungus near the second internode $>$ inch), and 7 to 9 is considered susceptible (7. fungus expanded to the second internode; 8 . invasion of the third internode $<1$ inch; 9 . invasion of the third internode $>$ linch leading to plant death). Capillary trays were placed under pots for watering from the bottom to prevent washing off the inoculum.

For the aggressiveness test G122, a partial 
physiological resistance to white mold (CARNEIRO et al., 2011), was inoculated with the $25 S$. sclerotiorum isolates from Brazil. A total of 250 pots each one with one seed were planted at the same time. Twenty-five pots were grouped together into a block where each pot received 1 of the 25 isolates. The experimental design was randomized complete blocks in each replication, with 10 replications where a replication was a complete set of 25 blocks.

\section{Data analyze}

The size of base pairs of each $S$. sclerotiorum isolate in each primer of microsatellite marker were analyzed with a multi variate statistical package (MVSP) software version 3.1 (KOVACH, 2005) to group all 25 isolates. The data was analyzed by means of unweighted pair-group method arithmetic average (UPGMA) algorithm based on squared Euclidean distances algorithm.
ZANCAN, W. L. A. et al.

Statistical analysis of variance (ANOVA) of the straw test were performed used the procedure PROC GLIMMIX in SAS 9.3 statistical software (SAS Institute, 2011). Data were analyzed using Scott-Knott and P-values less than 0.05 were considered significant.

\section{RESULTS}

The 25 S. sclerotiorum isolates from Brazil were grouped into clusters using a distance-based analysis of the data obtained from 8 microsatellite markers producing different base pair sizes. Four dendrograms, generated using Euclidean, Manhattan metric, Canberra metric and Squared Chord distance, produced the same structure and the same four different clusters with similarity indices of 24 , 32,30 and $28 \%$ (Figure 1).

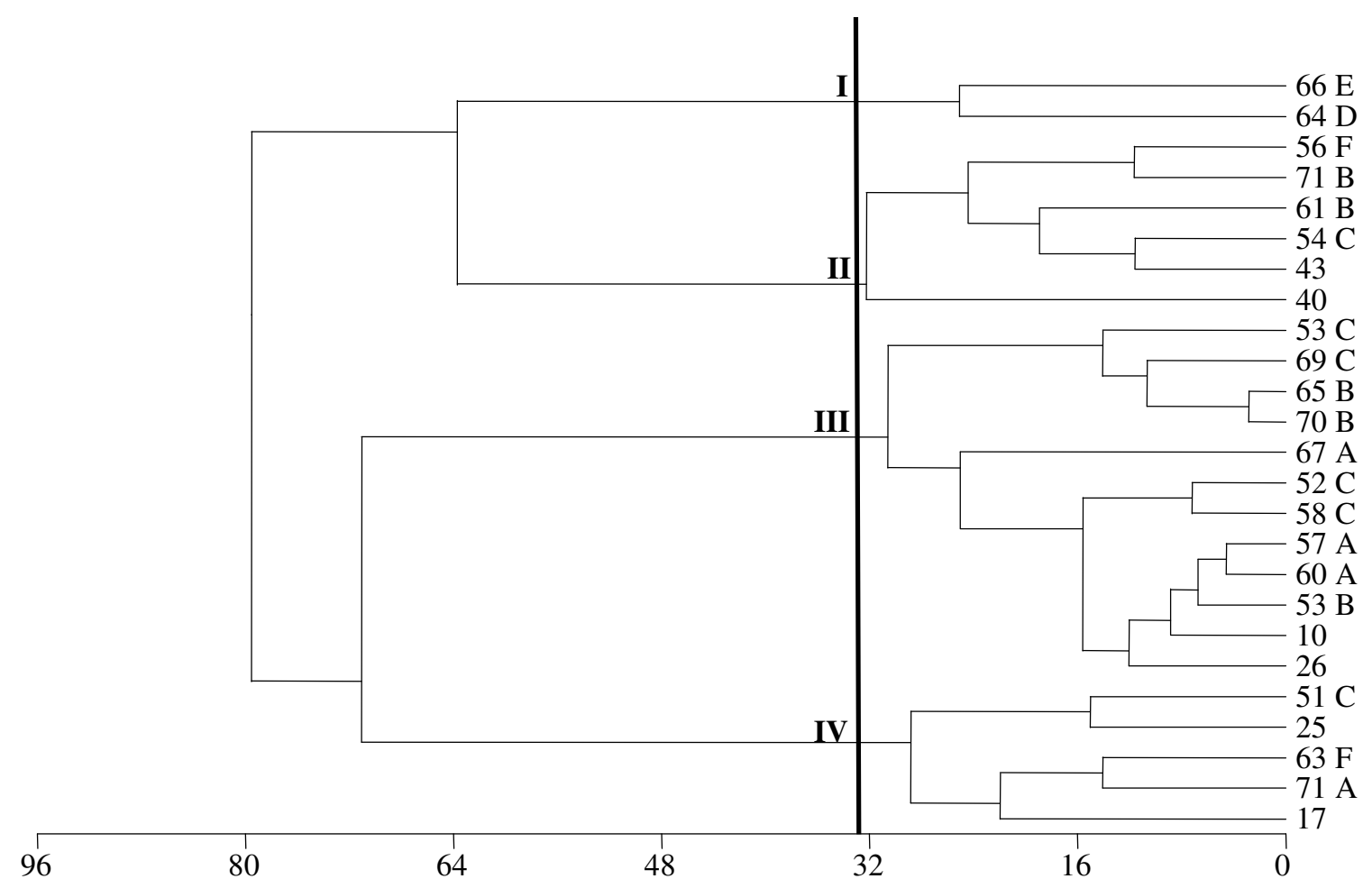

Euclidean

Figure 1. Unweighted pair group method using arithmetic means (UPGMA) cluster of the 25 Sclerotinia sclerotiorum isolates from different locations of Brazil (Table 1), constructed with a Euclidean distance algorithm based on data from eight fluorescently-labelled microsatellite primer pairs.

The first and smallest cluster (I) is made up of only two isolates, one from Oratórios (66E) and one from Viçosa (64D), both in Minas Gerais State. The second cluster (II) contains six isolates, two from Unaí, MG (56F, 61B) and one each from Porto Firme, MG (71B), Rio Verde, GO (54C), Lambari, MG (43) and Ijací, MG (40). All of the isolates that belong to a third (III) cluster can be divided in two 
sub-clusters. In one sub-cluster there are isolates from Paracatu, MG (53C, 53B), Goiânia, GO (69C), Canaã, MG (65B), Patos de Minas, MG (70B). The second sub-cluster includes isolates from Coimbra, MG (67A), Porto Firme, MG (52C), Lambari, MG (58C), Ventania, PR (57A), Irai de Minas, MG (60A), São Desidério, BA (10) and Campo Verde, MT (26). The fourth cluster (IV) has five isolates, one each from Rio Verde, GO (51C), Montividiu, GO (25), Lavras, MG (63F), Porto Firme, MG (71A) and Silvânia, GO (17). There did not appear to be any association of bean cultivar with genetic relatedness. An example is the cv. Pérola with isolates in MCGs B, C, E, F and in clusters II, III and IV.
For MCGs two data readings, 7 and 14 days post transfer, were consistent for all three observers and were summarized in a final data matrix. Among the 25 isolates, seven MCGs were identified (Table 2 and Figure 2). The Viçosa, Patos de Minas and Campo Verde isolates each were incompatible with all other isolates, making unique MCGs A, D and E, respectively. MCG C was widely distributed across the distance cluster, and includes $52 \%$ of the total isolates, including those from Minas Gerais, Bahia, Paraná and Goiás States. The MCGs F and G together accounted for $24 \%$ of the total isolates, obtained from Goiás and Minas Gerais State, respectively. The MCG B included isolates from Goiás and Minas Gerais States.

Table 2. The straw test rating mean and t grouping for each Sclerotinia sclerotiorum isolate tested for aggressiveness on G122 bean cultivar in the greenhouse and compared to 7 mycelial compatibility groupings (MCGs).

\begin{tabular}{cccc}
\hline MCGs & Location/Isolate & $\begin{array}{c}\text { Mean Straw Test } \\
\text { Rating }\end{array}$ & t Grouping \\
\hline C & Unaí, MG (61B) & 6.6 & $\mathrm{a}$ \\
C & Ventania, PR (57A) & 6.5 & $\mathrm{a}$ \\
G & Porto Firme, MG (71A) & 6.4 & $\mathrm{a}$ \\
B & Rio Verde, GO (54C) & 6.4 & $\mathrm{a}$ \\
G & Porto Firme, MG (71B) & 6.2 & $\mathrm{a}$ \\
C & Coimbra, MG (67A) & 6.2 & $\mathrm{a}$ \\
C & Porto Firme, MG (52C) & 6.0 & $\mathrm{a}$ \\
F & Montividiu, GO (25) & 5.9 & $\mathrm{a}$ \\
B & Unaí, MG (56F) & 5.9 & $\mathrm{a}$ \\
F & Rio Verde, GO (51C) & 5.9 & $\mathrm{a}$ \\
C & Canaã, MG (65B) & $\mathrm{a}$ \\
C & Lavras, MG (63F) & 5.8 & $\mathrm{a}$ \\
D & Patos de Minas, MG (70B) & 5.8 & $\mathrm{a}$ \\
C & Paracatu, MG (53B) & 5.7 & $\mathrm{a}$ \\
C & Irai de Minas, MG (60A) & 5.6 & $\mathrm{a}$ \\
C & Lambari, MG (58C) & 5.6 & $\mathrm{a}$ \\
F & Silvânia, GO (17) & 5.5 & $\mathrm{~b}$ \\
B & Ijací, MG (40) & 5.3 & $\mathrm{~b}$ \\
C & Paracatu, MG (53C) & 5.3 & $\mathrm{~b}$ \\
C & Lambari, MG (43) & 5.3 & $\mathrm{~b}$ \\
G & Oratórios, MG (66E) & 5.3 & $\mathrm{~b}$ \\
E & Campo Verde, MT (26) & 5.2 & $\mathrm{~b}$ \\
C & Goiânia, GO (69C) & 4.9 & $\mathrm{c}$ \\
C & São Desidério, BA (10) & 4.4 & $\mathrm{c}$ \\
A & Viçosa, MG (64D) & 4.2 & \\
& & 4.1 & \\
\hline
\end{tabular}




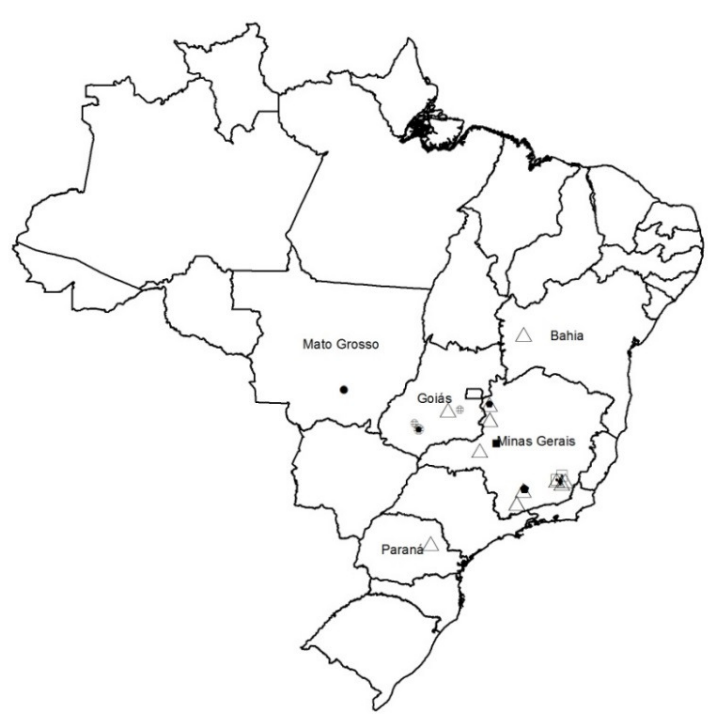

Figure 2. Associated of mycelial compatibility groups ( MCG 1, $\bullet$ MCG 2, $\triangle$ MCG 3, $\bullet$ MCG 4, $\bullet$ MCG 5, \# MCG 6 and $\square$ MCG 7) with locations of S. sclerotiorum isolate collections from bean field in 5 states in Brazil.

The aggressiveness ratings of 25 isolates, contained isolates that were significantly different from each other $(P=0.0002)$ (Table 2) and there were no significant differences due to blocking $(P=0.1186)$. The coefficient of variation $(\mathrm{CV})$ was $21.78 \%$. The straw test rating means per isolate on cultivar G122 ranged from 6.6 to 4.1. The aggressive isolates formed three different groups: the first was composed of isolates from Unaí (61B and 56F), Ventania (57A), Porto Firme (71A, 71B and 52C), Rio Verde (54C and 51C), Coimbra (67A), Montividiu (25), Canãa (65B), Lavras (63F), Patos de Minas (70B), Paracatu (53B), Iraí de Minas (60A) and Lambari (58C); the second group was made up of isolates from Silvânia (17), Ijací (40), Paracatu (53C), Lambari (43), Oratórios (66E) and Campo Verde (26) isolates; and the third group contained only the Goiânia (69C), São Desidério (10) and Viçosa (64D) isolates. Most of the isolates were classified as having intermediate aggressiveness, however there were significant differences among them.

Isolates with the highest aggressiveness rating or mean straw test ratings up to 6.0 , were found in MCGs G, C and B and included 66.6\%, $30.7 \%$ and $33.3 \%$ of isolates, respectively. The many isolates with intermediate aggressiveness included $100 \%$ of isolates in MCGs A, D, and F, $66.6 \%$ of isolates in MCG B, $69.2 \%$ of isolates in MCG C and $33.3 \%$ of isolates in MCG D.

\section{DISCUSSION}

Comparing genetic variation using microsatellite markers and MCGs, resulted in differing levels of variability observed among the isolates. This indicates that these isolates of $S$. sclerotiorum were not grouped by specific genetic characteristics. Previous reports of population studies reported a clonal mode of evolution for $S$. sclerotiorum, suggesting recombination, genetic exchange and mutation can occur (CARBONE et al., 1999; CUBETA et al., 1997; KOHLI; KOHN, 1998). LITHOLDO JÚNIOR et al. (2011) found that associated MCG and RAPD markers revealed a high level of variability among S. sclerotiorum isolates from different hosts and locations in Brazil. In a study of potato isolates from one field in the Washington Basin using microsatellite markers, high genetic diversity was found (ATALLAH et al., 2004). In some previous studies on S. sclerotiorum variation using microsatellite markers and MCGs, there was no relationship among the two genetic measures due to ecological adaptation of the pathogen and level of virulence of S. sclerotiorum isolates (AUCLAIR et al., 2004; KULL et al., 2004; MALVÁREZ et al., 2007; LITHOLDO JÚNIOR et al., 2011). Additionally, microsatellite loci have been reported to have high mutation rates (SIRJUSINGH; KOHN, 2001). The structure and 
dynamics f $S$. sclerotiorum populations represent an essential part of understanding how the underlying mechanisms are involved in the pathogen history and distribution between and within geographical areas and different hosts (CARBONE; KOHN 2001).

The variability found in 2 bean producer fields in Brazil using $21 \mathrm{~S}$. sclerotiorum isolates showed the presence of two MCGs (MEINHARDT et al., 2002), while Lehner et al. (2013) identified nine MCGs using 20 isolates from Minas Gerais (Zona da Mata and Northwest), São Paulo, Espiríto Santo and Parana states, including a mixture of isolates from different locations in the same MCGs. In this study, the largest group of compatible isolates was MCG C with $52 \%$ of $S$. sclerotiorum isolates from 11 geographic locations in different states. One of the most effective ways to disseminate the causal agent of white mold is the use of seeds contaminated with sclerotia (MACHADO, 1988) and/or the fungal mycelia within the teguments as well as in the embryonic tissues (TU, 1988). Introduction of the fungus to in non-infected areas or new pathotypes in the same areas by movement of seeds can help explain the genetic similarity among isolates in the same MCG.

When the greenhouse aggressiveness test was compared with isolate MCGs in the laboratory there were significant differences in aggressiveness within MCGs, e. g. MCG C. Otto-Hanson et al. (2011) only found significant differences between isolates in different MCGs and not among isolates in the same MCG in beans collected from the major bean production areas in the United States. The MCG structure of $S$. sclerotiorum on cultivated hosts appears to more complex, indicating that agricultural practices may influence MCG frequencies and patterns which, can help to explain the results across field locations (KULL et al., 2004).

Characterizing $S$. sclerotiorum population structure and variability in isolate aggressiveness can guide development of management strategies, reducing the loss in yield and quality of crops caused by this pathogen, not only in Brazil, but around the world where this pathogen is present or may be introduced.

\section{ACKNOWLEDGMENTS}

We thank Oscar Perez-Hernandez and Dr. Kent Eskridge Departments of Plant Pathology and Statistic, respectively, of the University of Nebraska-Lincoln for help in statistical analysis. Thanks are also due to $\mathrm{CNPq}$ and CAPES for supporting part of this project.

RESUMO: A infecção de Sclerotinia sclerotiorum em campos de feijoeiro tem aumentado no Brasil. A aplicação de fungicidas é a estratégia de controle utilizada devido à falta de cultivares com resistência completa á doença. Para orientar o uso de isolados visando resistência, 25 isolados de S. sclerotiorum coletados em campos de feijoeiro no Brasil foram caracterizados utilizando marcadores microssatélites, grupos de compatibilidade micelial (MCGs) e agressividade. Pares de primers de microssatélites foram utilizados para identificar polimorfismo entre os isolados de $S$. sclerotiorum e MCGs foram determinados a partir de interação dos isolados crescendo lado-a-lado. O teste de agressividade foi derivado a partir do straw test onde o micélio do fungo foi depositado sobre a haste cortada de feijoeiro e avaliado o progresso da doença. Os dados de microssatélites dos 25 isolados de S. Sclerotiorum foram agrupados em quatro grupos e identificados sete MCGs. Não foi observada associação entre a cultivar hospedeira e o cluster ou MCG dos isolados. Para MCGs, 57\% continham isolados amostrados em vários locais e $43 \%$ continham isolados de apenas um local. Houve diferença significativa entre os isolados na agressividade dentro e entre os MCGs. O isolado mais agressivo no screening de resistência será útil na identificação de níveis mais elevados de resistência em germoplasma/linhagens de feijoeiro.

PALAVRAS-CHAVE: Agressividade. Microssatélite. Resistência. Mofo branco.

\section{REFERENCES (inserir local de publicação. Link para pesquisa: http://ccn.ibict.br/busca.jsf )}

ATALLAH, Z. K.; LARGET, B.; CHEN, X.; JOHNSON, D. A. High genetic diversity, phenotypic uniformity, and evidence of outcrossing in Sclerotinia sclerotiorum in the Columbia Basin of Washington State.

Phytopathology, v. 94, p. 737-742, 2004. http://dx.doi.org/10.1094/PHYTO.2004.94.7.737 
AUCLAIR, J.; BOLAND, G. J.; KOHN, L. M.; RAJCAN, I. Genetic interactions between Glycine max and Sclerotinia sclerotiorum using a straw inoculation method. Plant Disease, v. 88, p. 891-895, 2004. http://dx.doi.org/10.1094/PDIS.2004.88.8.891

BOLTON, M. D.; THOMMA, B. P. H. J.; NELSON, B. D. Sclerotinia sclerotiorum (Lib.) de Bary: biology and molecular traits of a cosmopolitan pathogen. Molecular Plant Pathology, v. 7, p. 1-16, 2006.

http://dx.doi.org/10.1111/j.1364-3703.2005.00316.x

CARBONE, I.; ANDERSON, J. B.; KOHN, L. M. Patterns of descent in clonal lineages and their multilocus fingerprints are resolved with combined gene genealogies. Evolution, v. 53, p. 11-21, 1999.

http://dx.doi.org/10.2307/2640916

CARBONE, I.; KOHN, L. M. A microbial population-species interface: nested cladistic and coalescent inference with multilocus data. Molecular Ecology, v. 10, p. 947-64, 2001. http://dx.doi.org/10.1046/j.1365294X.2001.01244.x

CARNEIRO, F. F.; ZEVIANI, W. M.; SANTOS, J. B.; CARVALHO, R. S. B.; ALVES, F. C.; DIAS, J. A. Minimum number of common bean plants per plot assess field resistance to white mold. Crop Breeding and Applied Biotecnology, v. 11, p. 358-364, 2011. http://dx.doi.org/10.1590/S1984-70332011000400010

CUBETA, M.A.; CODY, B. R.; KOHLI, Y.; KOHN, L. M. Clonality in Sclerotinia sclerotiorum in infected cabbage in eastern North Carolina. Phytopathology, v. 87, p. 1000-1004, 1997.

http://dx.doi.org/10.1094/PHYTO.1997.87.10.1000

CUBETA, M. A.; SERMONS, D. N.; CODY, B. R. Mycelial interactions of Sclerotinia minor. (Abstr.) Phytopathology, v. 91, p. S19, 2001.

CLARKSON, J. P.; COVENTRY, E.; KITCHEN, J.; CARTER, H. E.; WHIPPS, J. M. Population structure of Sclerotinia sclerotiorum in crop and wild hosts in the UK. Plant Pathology, v. 62, p. 309-324, 2013. http://dx.doi.org/10.1111/j.1365-3059.2012.02635.x

HAMBLETON, S.; WALKER, C.; KOHN, L. M. Clonal lineages of Sclerotinia sclerotiorum previously known from other crops predominate in 1999-2000 samples from Ontario and Quebec soybean. Canadian Journal of Plant Pathology, v. 24, p. 309-15, 2002. http://dx.doi.org/10.1080/07060660209507014

HAWTHORNE, B. T.; JARVIS, W. R. Differential activity of fungicides on various stages in the life cycle of Sclerotinia spp. New Zealand Journal Agricultural Research, v. 16, p. 551-557, 1973.

http://dx.doi.org/10.1080/00288233.1973.10421103

KOHN, L. M. The clonal dynamic in wild and agricultural plant-pathogen populations. Canadian Journal of Botany, v. 73, p. 1231-1240, 1995. http://dx.doi.org/10.1139/b95-383

KOHN, L. M.; CARBONE, I.; ANDERSON, J. B. Mycelial interactions in Sclerotinia sclerotiorum.

Experimental Mycology, v. 14, p. 255-267, 1990. http://dx.doi.org/10.1016/0147-5975(90)90023-M

KOHLI, Y.; KOHN, L. M. Random association among alleles in clonal populations of Sclerotinia sclerotiorum. Fungal Genetic Biology, v. 23, p. 139-149, 1998. http://dx.doi.org/10.1006/fgbi.1997.1026

KOVACH, W. L. MVSP_A Multivariate Statistical Package for Windows, ver. 3.1.

Kovach Computing Services, Pentraeth, Wales, U.K, 2005.

KULL, L. S.; PEDERSEN, W. L.; PALMQUIST, D.; HARTMAN, G. L. Mycelial compatibility grouping and aggressiveness of Sclerotinia sclerotiorum. Plant Disease, v. 88, p. 325-332, 2004.

http://dx.doi.org/10.1094/PDIS.2004.88.4.325 
LEHNER, M. S.; PAULA JÚNIOR, T. J.; LIMA, R. C.; VIEIRA, R. F.; SOARES, B. A.; CRUZ NETO, L. B. M.; CARNEIRO, J. E. S. Mycelial compatibility grouping and aggressiveness of Sclerotinia sclerotiorum isolates from four states of Brazil. Annual Report Bean Improvement Cooperation, v. 56, p. 53-54, 2013.

LITHOLDO JÚNIOR, C. G.; GOMES, E. V.; LOBO JÚNIOR, M.; NASSER, L. C. B.; PETROFEZA, S. Genetic diversity and mycelial compatibility groups of the plant-pathogenic fungus Sclerotinia sclerotiorum in Brazil. Genetics and Molecular Research, v. 10, n. 2, p. 868-877, 2011. http://dx.doi.org/10.4238/vol102gmr937

MACHADO, J. C. Patologia de sementes: fundamentos e aplicações. Lavras: ESAL/FAEPE, pp. 107, 1988.

MALVÁREZ, M.; CARBONE, I.; GRÜNWALD, N. J.; SUBBARAO, K. V.; SCHAFER, M.; KOHN, L. M. New populations of Sclerotinia sclerotiorum from lettuce in California and peas and lentils in Washington.

Phytopathology, v. 97, p. 470-483, 2007. http://dx.doi.org/10.1094/PHYTO-97-4-0470

MEINHARDT, L. W.; WULFF, N. A.; BELLATO, C. M.; TSAI, S. M. Telomere and microsatellite primers reveal diversity among Sclerotinia sclerotiorum isolates from Brazil. Fitopatologia Brasileira, v. 27, p. 211215, 2002. http://dx.doi.org/10.1590/S0100-41582002000200015

OTTO-HANSON, L.; STEADMAN, J. R.; HIGGINS, R.; ESKRIDGE, K. M. Variation in Sclerotinia sclerotiorum bean isolates from multisite resistance screening locations. Plant Disease, v. 95, p. 1370-1377, 2011. http://dx.doi.org/10.1094/PDIS-11-10-0865

PARIUAD, B.; RAVIGNE, V.; HALKETT, F.; GOYEAU, H.; CARLIER, J.; LANNOU, C. Aggressiveness and its role in the adaptation of plant pathogens. Plant Pathology, v. 58, p. 409-424, 2009.

http://dx.doi.org/10.1111/j.1365-3059.2009.02039.x

SAS INSTITUTE. The SAS system for windows: Release 9.3. SAS Institute, Inc., Cary, NC, 2011.

SAMBROOK, J.; RUSSEL, D. Molecular Cloning: A Laboratory Manual, vol. 3, Cold Spring Harbor Laboratory Press, New York, NY, USA, 3rd edition, pp. 2344, 2001.

SCHAFER, M. R.; KOHN, L. M. An optimized method for mycelial compatibility testing in Sclerotinia sclerotiorum. Mycologia, v. 98, n. 4, p. 593-597, 2006. http://dx.doi.org/10.3852/mycologia.98.4.593

SIRJUSINGH, C.; KOHN, L. M. Characterization of microsattelites in the fungal plant pathogen, Sclerotinia sclerotiorum. Molecular Ecology Notes , v. 1, n. 4, p. 267-269, 2001. http://dx.doi.org/10.1046/j.14718278.2001.00102.x

TERAN, H.; LEMA, M.; SCHWARTZ, H. F.; DUNCAN, R.; GILBERTSON, R.; SINGH, S. P. Modified Petzoldt and Dickson scale for white mold rating of common bean. Ann. Rep. Bean Improvement Cooperation, v. 49, p. 115-116, 2006.

TU, J. C. The role of White mold-infected white bean (Phaseolus vulgaris L.) seeds in the dissemination of Sclerotinia sclerotiorum (Lib.) de Bary. Journal of Phytopathology, v. 121, p. 40-50, 1988. http://dx.doi.org/10.1111/j.1439-0434.1988.tb00951.x 